Seminars, Conferences, Addresses

\title{
The 203rd Third Meeting of the American Oriental Society
}

\author{
25 - 28 Shawwäl 1413 / 18 - 21 April 1993 \\ Chapel Hill, North Carolina
}

The annual meeting featured panels on the Ancient Near East and Art History; East Asia; Islam, South, and Southeast Asia; The Ancient Near East; and Linguistics. In this report the sessions on Islam are covered.

The first day dealt with Islamic history. Khalid Blankinship (Temple University, Philadelphia, PA) exploned "The Background of Sayf ibn "Umar (d. c. 180/796) and the Nature of His Sources." Sidney H. Griffith (Catholic University of America, Washington, DC) spoke on "Muhammad and the Monk Bahira: Reflections on a Syriac Apologetical Text from Abbasid Times." Tayeb el-Hibri (Columbia University, New York, NY) spoke on "The Regicide of the Caliph al-Amin and the Challenge of Representation in Medieval Islamic Historiography." Christopher Melchert (Wake Forest University, Winston-Salem, NC) explicated the religious 
policies of the caliphs from al Mutawakkil to al Muqtadir as expressed by their judicial appointments. Closing this session was Chase F. Robinson (Middlebury College, Middlebury, VT), who informed the participants that the coincidence of plague, flooding, earthquake, locusts, and imperial warfare conspired to cause significant social dislocation among the settled communities of the Syro-Mesopotamian plain.

On the second day, six papers were presented during the first session. James A. Bellamy (University of Michigan, Ann Arbor, MI) talked about the techniques used by early Muslim Qur'anic commentators and suggested new readings of Qur'an 2:226. He could not offer new meanings and accepted the suggestions of the early commentators. Boustan Hirji (Dawson Community College, Glendive, MT) spoke on "Islamic Neoplatonism: Primacy of the Intellect?" and presented the case of the Ismā'î̄i Abū Ya'qūb al Sijistānī (d. between 991-1003). She concluded that while he outwardly maintains a Neoplatonic structure of the intellect's priority, this is simply a logical priority, for at the ontological and functional levels, the primacy of the soul is clear. Richard M. Frank (Catholic University of America, Washington, DC) presented "The Chronology of al Ghazālī's Writings," and was followed by Rosalind Gwynne (University of Tennessee, Knoxville, TN), who suggested, in her "The Neglected Sunnah: Sunnat Allah" that, when pondering the possible alteration of early textual references to sunnah, if the original reference might have been to the sunnah of God instead of to that of the Prophet or the community. Irfan Shahid (Georgetown University, Washington, DC) commented on the first nine verses of Surat al Burüj and argued, based on their contents and language, that they do not refer to Najrān and the persecution of Christians therein. Davis J. Stewart (Emory University, Atlanta, GA) discussed the problem of authority and orthodoxy in Islam. He seems to argue that these did exist in Islam and, to strengthen his view, presented the case of Salman Rushdi.

The second session dealt with Islamic law and its principles. Michael G. Carter (New York University, New York, NY) used his "Legal and Grammatical Reasoning" to discuss the origins of "illa" and "qiyās" in legal and grammatical reasoning. The paper offers a small specimen from Ibn Rushd to show how an argument can begin with a syllogism and end with an analogy according to the requirements of the topic. Marie Bernand (Paris) compared the views of al Shāfi' $1 \overline{1}$ and Jassās on bayān and concluded that the latter's definition was more comprehensive. Sherman A. Jackson (Indiana University, Bloomington, IN) spoke on muțlaq and 'amm in al Qarāfî's jurisprudence. Rudolph Peters (University of Amsterdam, the Netherlands) shed some light on the application of the Shari'ah in criminal matters in Egypt before the introduction of western law codes 
in 1883. He could not find a single instance where such penalties as amputation and stoning to death had been implemented. According to him, the Shari'ah was limited mainly to settling private claims arising from criminal acts. The final paper was given by Lutz Wiedserhold (Germany), who spoke on "Some Remarks on the Manuscript Ușūl Taymūr 94 (Dār al Kutub, Cairo): An Anonymous Risālah fí al Ijtihād wa al Taqlīd.

The plenary session discussed the classification of knowledge in Islam, while the afternoon session dealt with different topics of Islamic literature. Soheila Amirsoleimani talked about al Baybaqi's treatment of al Mas'ūd's court, his explanation of "how history occurs," and the historian's view of the use of intrigue in court politics. Lawrence I. Conrad (Welcome Institute) presented "al Jāhiz on the Ralative Merits of SlaveBoys and Slave-Girls: An Epistemological Metaphor?" He thinks that in the literary circles of early Islamic times, sexual matters were discussed candidly, were an open subject of amusement, and that al Jāhiz mocked those who considered them obscene or shameful. Leila S. Al- Imad (East Tennessee State University, Johnson City, TN) read a paper on "Sexuality and Sexual Discourse in Arabic Literature." She opines that, in medieval literature, sex was not so much a taboo as one would expect and that it was tackled by both jurisprudents and lay writers. The following papers, "Ritual Purity and Political Exile: The Seduction of the Queen of Sheba in a Judeo-Islamic Folktale" and Anvari's "Tears of Khurasan" were presented by Jacob Lassner (Wayne State University, Detroit, MI) and K. Allin Luther (University of Michigan, Ann Arbor, MI), respectvely.

The final session featured Muhammad Akram (Villanova University, Villanova PA), who spoke on the attitude of American orientalists on the principles of Islamic jurisprudence. He asserted that American views on many aspects of Islam and Muslims come from Europe. Norman Cigar dealt with "Heresy and Orthodoxy in Pre-Colonial Morocco," and Thomas D. Goodrich (Indiana University of Pennsylvania, Indiana, PA) showed the maps of Istanbul in the Kitab-i-Bahirye of Piri Reis.

The presidential address was delivered by Throkild Jacobson at the end of the annual subscription dinner. He highlighted the importance of the early history of the ancient East. After selecting the new president for the 204th meeting of the society, the socitey meeting was was finalized.

Muhammad Akram

Fulbright Scholar Center for Arab and Islamic Studies Villanova University Villanova, Pennsylvania 